\title{
Trophic relationships in an intertidal rockpool fish assemblage in the gulf of Cádiz (NE Atlantic)
}

\author{
E.M. Velasco *, M.C. Gómez-Cama, J.A. Hernando, M.C. Soriguer \\ Lab. Dinamica de Poblaciones de Peces, Dpto. Biologia, Ftad. CCMar y Amb., Universidad de Cádiz, CASEM, Campus De Puerto Real, Cádiz, Spain
}

\section{A R T I C L E I N F O}

Available online 20 October 2009

Keywords:

Trophic relationships

Intertidal fishes

Diet

Rockpool

NE Atlantic

\begin{abstract}
A B S T R A C T
Many species of littoral fish that live in rocky substrates are syntopic, sharing the same coastal habitat. They have similar feeding behaviours and use small hollows as places to hide and spawn. In the present study, we identified a total of 16 resident fish species in a rockpool assemblage in the Gulf of Cádiz and studied their patterns of co-occurrence. The dietary analysis performed showed the occurrence of 2 mainly herbivorous species (Lipophrys canevae and Parablennius sanguinolentus), 8 mainly carnivorous species with a percentage occurrence of algae in the diet below 10\% (Gobius paganellus, Gobius cobitis, Gobius bucchichi, Clinitrachus argentatus, Tripterygion delaisi, Lepadogaster lepadogaster, Lepadogaster purpurea and Lepadogaster candolii), and 6 species that are carnivorous in the earlier phases of their lives and gradually increase the proportion of algae in their diet (Lipophrys pholis, Paralipophrys trigloides, Parablennius incognitus, Salaria pavo, Coryphoblennius galerita and Symphodus roissali). The dietary overlap among the different species does not explain the different patterns of abundance found among co-occurring species. In the present study, the common use of abundant resources coupled with specialized use of other types of resources was observed, and this allows the different species to minimise the effects of possible trophic competition.
\end{abstract}

(c) 2009 Elsevier B.V. All rights reserved.

\section{Introduction}

Many resident intertidal fish species are syntopic, sharing the same coastal habitats, exhibiting similar feeding behaviours, and using small hollows as shelters to hide from predators and to spawn (Nieder, 1997). Numerous studies have segregated species by vertical distribution or according to bathymetry, with varying degrees of overlap (Gibson, 1982; Illich and Kotrschal, 1990; Macpherson, 1994). However, the studied intertidal rockpool ecosystem does not allow a high degree of vertical spatial segregation. It is therefore necessary to study the trophic relationships of the species in order to understand the functioning of this intertidal fish assemblage. Coexistence of different species in the ecosystem can be explained based on the separation of the species into different ecological niches (Zander and Berg, 1984). This separation avoids possible competition among nonspecialized consumers on the same trophic levels, with the different coexisting fish species presenting differences in the type and/or size of their respective prey (Morton et al., 2008). The calculation of trophic overlap provides information on the degree of dietary competition among the species (Colwell and Futuyma, 1971; Mayr and Berger, 1992). Resource partitioning in fish assemblages can be manifested in several ways, including the segregation of prey based on type or size and the partitioning of habitat, both temporally and spatially (Davis, 2000).

\footnotetext{
* Corresponding author.

E-mail address: evamaria.velasco@gmail.com (E.M. Velasco).
}

Resident intertidal fishes have been poorly studied along the Atlantic coasts of the Iberian Peninsula, with studies limited to the Portuguese coast (e.g. Nieder, 1993; Monteiro et al., 1998, 2005; Almada et al., 1996; Faria and Almada, 2001a,b; Faria et al., 1996, 1998) and the Cantabrian coast (Mazé, 2004). In the practically non-tidal Mediterranean Sea there is also a scarceness of studies directed at the study of strictly littoral fish (e.g. Moranta et al., 1997; Vicent and Aparici, 1997).

The main objective of the present study is to provide information on the patterns of co-occurrence of the different fish species present in an intertidal rockpool assemblage in the Gulf of Cádiz (NE Atlantic), to study the diet of the different species, and to analyse the degree of dietary overlap among them to ascertain the ecological patterns of dietary interrelationships within the fish assemblage.

\section{Materials and methods}

Fishes were collected monthly from March 2003 through March 2004 in a rocky intertidal zone in the Gulf of Cádiz ( $\left.36^{\circ} 28^{\prime} \mathrm{N} ; 006^{\circ} 15^{\prime} \mathrm{W}\right)$, along the beaches of El Chato and Torregorda. Fish were captured during diurnal low-tide periods from the rockpools by using anesthetic clove oil, dissolved in ethanol in the ratio of 1:5, in a concentration of $40 \mathrm{mg} \mathrm{l}^{-1}$ (Griffiths, 2000). After a short time the anesthetized fish could be captured with a hand-net. The specimens collected were killed immediately after capture with an overdose of clove oil, kept in ice to halt digestion and transported to the nearby laboratory where each specimen was measured (total length $=\mathrm{TL}$ ) to the nearest millimeter. 
Fish guts were removed and the contents wet weighted and preserved in $70 \%$ ethanol for taxonomic assessment and quantification.

The co-occurrence values for species pairs were based on the presence and absence data of the species pairs in the different pools, and were calculated as a percentage of pools occupied by a species where another species was present. The statistical program used was Statgraphics Plus 5.1.

Prey items from each gut were placed into a Petri dish, examined under a dissection microscope and identified to the lowest possible taxonomic resolution. Dietary results are presented as percentage occurrence $(\% \mathrm{~F})$ in the stomachs (number of stomachs that contain a particular item, divided by the total number of stomachs analysed), and as relative abundance $(\% \mathrm{~N})$ (number of a particular prey item divided by the total number of prey found). The overlap in resource use was calculated using Shoener's index $S\left(S=1-0.5\left|p_{\mathrm{ij}}-p_{\mathrm{ik}}\right|\right.$, where $p_{i j}$ and $p_{i k}$ are the frequency of the resource $i$ in the diet of the species $j$ and $k$ respectively) (Krebs, 1989), in which values range from 0 to 1 , indicating null to complete dietary overlap. We considered the overlap to be significant when $S \geq 0.6$ (Zaret and Rand, 1971).

\section{Results}

\subsection{Co-occurrence of fish species}

A total of 16 fish species, belonging to the families Gobiidae, Blenniidae, Tripterygiidae, Clinidae, Gobiesocidae and Labridae, were collected in the study area (Table 1).

The degree of co-occurrence of each pair of species is shown in Table 2 (notice that is not a symmetric matrix). Thus, for example, Gobius cobitis is present in $16 \%$ of the sites occupied by Gobius paganellus, but G. paganellus is present in $91.7 \%$ of the sites occupied by $G$. cobitis. All the species showed a high degree of co-occurrence

Table 1

Number of each fish species collected $(n)$ in the studied area.

\begin{tabular}{|c|c|c|c|c|c|}
\hline Species & Family & $n$ & $\begin{array}{l}\mathrm{TL} \\
\text { Average }\end{array}$ & $\begin{array}{l}\mathrm{TL} \\
\text { minimum }\end{array}$ & $\begin{array}{l}\mathrm{TL} \\
\text { maximum }\end{array}$ \\
\hline $\begin{array}{l}\text { Gobius paganellus } \\
\quad \text { (Linnaeus, 1758) }\end{array}$ & Gobiidae & 788 & 66.4 & 12.8 & 99.9 \\
\hline $\begin{array}{l}\text { Gobius cobitis } \\
\quad \text { (Pallas, 1811) }\end{array}$ & Gobiidae & 59 & 66.4 & 23.5 & 186 \\
\hline $\begin{array}{l}\text { Gobius bucchichi } \\
\quad \text { (Steindachner, 1980) }\end{array}$ & Gobiidae & 83 & 51.8 & 18.2 & 88.7 \\
\hline $\begin{array}{l}\text { Lipophrys pholis } \\
\quad \text { (Linnaeus, } 1758 \text { ) }\end{array}$ & Blenniidae & 151 & 45.6 & 14.1 & 114 \\
\hline $\begin{array}{l}\text { Lipophrys canevae } \\
\quad \text { (Vinciguerra, 1680) }\end{array}$ & Blenniidae & 18 & 44.5 & 26.4 & 57.6 \\
\hline $\begin{array}{l}\text { Paralipophrys trigloides } \\
\text { (Valenciennes, 1836) }\end{array}$ & Blenniidae & 102 & 52.7 & 15.5 & 92.4 \\
\hline $\begin{array}{l}\text { Parablennius incognitus } \\
\text { (Bath, 1968) }\end{array}$ & Blenniidae & 186 & 43.9 & 26.1 & 62.5 \\
\hline $\begin{array}{l}\text { Parablennius sanguinolentus } \\
\quad \text { (Pallas, 1811) }\end{array}$ & Blenniidae & 9 & 118 & 93 & 143 \\
\hline Salaria pavo (Risso, 1810) & Blenniidae & 82 & 55 & 15.6 & 87.1 \\
\hline $\begin{array}{l}\text { Coryphoblennius galerita } \\
\text { (Norman, 1943) }\end{array}$ & Blenniidae & 59 & 42.6 & 24.7 & 64.4 \\
\hline $\begin{array}{l}\text { Clinitrachus argentatus } \\
\quad \text { (Risso, 1810) }\end{array}$ & Clinidae & 38 & 43.2 & 32.5 & 60.9 \\
\hline $\begin{array}{l}\text { Tripterygion delaisi } \\
\quad \text { (Cadenat \& Blache, 1971) }\end{array}$ & Tripterygiidae & 37 & 47 & 30.6 & 63.8 \\
\hline $\begin{array}{l}\text { Lepadogaster purpurea } \\
\text { (Bonnaterre, 1788) }\end{array}$ & Gobiesocidae & 32 & 31.9 & 23.2 & 40.6 \\
\hline $\begin{array}{l}\text { Lepadogaster lepadogaster } \\
\text { (Bonnaterre, 1788) }\end{array}$ & Gobiesocidae & 6 & 33.4 & 20 & 37.8 \\
\hline $\begin{array}{l}\text { Lepadogaster candolii } \\
\quad \text { (Risso, 1810) }\end{array}$ & Gobiesocidae & 5 & 39.9 & 29.4 & 46.8 \\
\hline $\begin{array}{l}\text { Simphodus Roissali } \\
\quad \text { (Risso, 1810) }\end{array}$ & Labridae & 38 & 69.3 & 38.2 & 120.5 \\
\hline
\end{tabular}

Fishes total length (TL) in $\mathrm{mm}$. with G. paganellus because of the high abundance and high percentage occurrence of that species in the study area. In the same way, most species showed a high co-occurrence with the most abundant blenniid, Parablennius incognitus. Gobiesocids, clinids and blenniids were also highly co-occurrent with Paralipophrys trigloides. G. cobitis and Parablennius sanguinolentus showed a co-occurrence of $60 \%$, this latter species showing a high co-occurrence with all the blenniids except Coryphoblennius galerita. Lipophrys pholis showed the same pattern of $P$. sanguinolentus, being highly co-occurrent with all the blenniids except Salaria pavo. The remaining species did not show a high level of co-occurrence.

\subsection{Species diet}

The percentage occurrence of prey is shown in Table 3. All prey caught by intertidal fishes in this study were invertebrates. Crustaceans were the most highly represented taxon, comprising mainly amphipods, followed by copepods and tanaids. Other well-represented crustaceans were isopods, cumaceans, ostracods, caprellid amphipods and decapods. The most abundant molluscs were gastropods, followed by bivalves and polyplacophorans. Polychates and chironomid insects were also present in the diets, as were acari and pycnogonids. Algae appear in $100 \%$ of the guts of the herbivorous species (Parablennius sanguinolentus and Lipophrys canevae), and in $20 \%$ and $35 \%$ in the omnivorous species (Parablennius incognitus, Coryphoblennius galerita, Salaria pavo, S. roissali), and below $10 \%$ in the carnivorous species (gobiids, L. pholis, Paralipophrys trigloides, Tripterygion delaisi and gobioesocids).

The relative abundance of prey in the gut contents is shown by species in Table 4. A wide variety of prey is present in the diet of gobiids, mainly harpacticoid copepods and amphipods. Harpacticoids copepods were also abundant in the diets of Gobius paganellus and $G$. bucchichi, whereas larger amphipods were abundant in the diet of the largest goby, G. cobitis. Crabs were only present in the guts of $G$. cobitis and G. paganellus. In the other hand, the diet of the blenniids varied widely. Filamentous green algae were the basic components of the diet of Lipophrys canevae and Parablennius sanguinolentus, whereas the smaller blenniids (Parablennius incognitus and Coryphoblennius galerita) ate mainly harpacticoids copepods, amphipods and tanaids. Medium-sized blennies (Paralipophrys trigloides and Salaria pavo) consumed amphipods, isopods (mainly belonging to the family Sphaeromatidae) and tanaids. The largest non-herbivorous blenniid, L. pholis, ate mainly gastropods (specially Littorina neritoides) and amphipods. Clinitrachus argentatus consumed principally amphipods whereas Tripterygion delaisi ate more harpacticoids copepods and the gastropod Barleeia rubra. Although all members of the Gobiesocidae ate harpacticoids copepods and amphipods, the diets of the various species differed because of the presence of polyplacophorans and the gastropod Rissoa sp. Copepods, gastropods and amphipods constituted the main components of the diet of Symphodus roissali.

Since consumption of algae was very important in five blenniid species, its percentage occurrence per size class was analysed (Fig. 1). It can be clearly seen that, in all five species, namely Lipophrys pholis, Paralipoprhys trigloides, Salaria pavo, Parablennius incognitus and Coryphoblennius galerita, algal consumption increased with fish size.

\subsection{Dietary overlap}

We performed a cluster analysis based on the similarity of diets found between the different species (Fig. 2). The assemblage can be divided into 2 groups. The first is formed by Gobius paganellus, $G$. bucchichi, Coryphoblennius galerita and Parablennius incognitus, and Lipophrys canevae. G. paganellus, the predominant species in the assemblage, overlapped significantly in diet with $P$. incognitus, $C$. galerita and G. bucchichi, and the co-occurrence among these four species was more than $75 \%$ (Table 2). G. bucchichi also overlapped 
Table 2

Co-occurrence of the fish species collected.

\begin{tabular}{|c|c|c|c|c|c|c|c|c|c|c|c|c|c|c|c|c|}
\hline$\%$ Oc & Gcob & Gpag & Gbuc & Lcane & Lpho & Ptri & Pinc & Psan & Spav & Cgal & Carg & Tdel & Llep & Lpur & Lcand & Sroi \\
\hline Gcob & 100 & 16.2 & 7.1 & 12 & 10 & 6.7 & 15.2 & 60 & 22.2 & 0 & 16 & 15.8 & 0 & 7.1 & 0 & 7.7 \\
\hline Gpag & 91.7 & 100 & 97.6 & 92.0 & 100 & 76.7 & 86.4 & 100 & 95.6 & 76.5 & 84 & 89.5 & 100 & 57.1 & 75 & 92.3 \\
\hline Gbuc & 12.5 & 30.1 & 100 & 32 & 30 & 20 & 22.7 & 20 & 33.3 & 14.7 & $\underline{40}$ & 31.6 & 20 & $\overline{0}$ & 25 & 34.6 \\
\hline Lcane & 25 & 33.8 & 38.1 & 100 & 70 & 38.3 & 27.3 & 60 & 44.4 & 55.9 & $\overline{12}$ & 15.8 & 40 & 14.3 & 0 & 19.2 \\
\hline Lpho & 4.2 & 7.4 & 7.1 & 14 & 100 & 11.7 & 9.1 & 100 & $\overline{4.4}$ & $\overline{14.7}$ & 8 & 10.5 & $\overline{0}$ & 0 & 0 & 7.7 \\
\hline Ptri & 16.7 & 33.8 & 28.6 & 46 & 70 & 100 & 53 & 40 & 24.4 & 73.5 & 40 & 36.8 & 100 & 71.4 & 50 & 30.8 \\
\hline Pinc & $\underline{41.7}$ & $\underline{41.9}$ & 35.7 & $\overline{36}$ & 60 & 58.3 & $\overline{100}$ & $\overline{40}$ & 33.3 & 41.2 & $\overline{64}$ & 78.9 & 80 & 57.1 & $\overline{100}$ & 50 \\
\hline Psan & $\overline{12.5}$ & $\overline{3.7}$ & 2.4 & 6 & 50 & 3.3 & 3 & $\overline{100}$ & 4.4 & 0 & 0 & 0 & 0 & 0 & 0 & $\overline{0}$ \\
\hline Spav & 41.7 & 31.6 & 35.7 & 40 & $\overline{20}$ & 18.3 & 22.7 & 40 & 100 & 23.5 & 20 & 21.1 & 0 & 14.3 & 0 & 15.4 \\
\hline Cgal & $\overline{0}$ & 19.1 & 11.9 & $\overline{38}$ & 50 & 41.7 & 21.2 & $\overline{0}$ & 17.8 & 100 & 8 & 15.8 & 20 & 35.7 & 25 & 11.5 \\
\hline Carg & 16.7 & 15.4 & 23.8 & 6 & $\overline{20}$ & $\overline{16.7}$ & 24.2 & 0 & 11.1 & 5.9 & 100 & 31.6 & 20 & 0 & 0 & 34.6 \\
\hline Tdel & 12.5 & 12.5 & 14.3 & 6 & 20 & 11.7 & 22.7 & 0 & 8.9 & 8.8 & 24 & 100 & 20 & 7.1 & 25 & 19.2 \\
\hline Llep & 0 & 3.7 & 2.4 & 4 & 0 & 8.3 & 6.1 & 0 & 0 & 2.9 & 4 & 5.3 & 100 & 7.1 & 0 & 3.8 \\
\hline Lpur & 4.2 & 5.9 & 0 & 4 & 0 & 16.7 & 12.1 & 0 & 4.4 & 14.7 & 0 & 5.3 & 20 & 100 & 0 & 7.7 \\
\hline Lcand & 0 & 2.2 & 2.4 & 0 & 0 & 3.3 & 6.1 & 0 & 0 & 2.9 & 0 & 5.3 & 0 & 0 & 100 & 0 \\
\hline Sroi & 8.3 & 17.6 & 21.4 & 10 & 20 & 13.3 & 19.7 & 0 & 8.9 & 8.8 & 36 & 26.3 & 20 & 14.3 & 0 & 100 \\
\hline
\end{tabular}

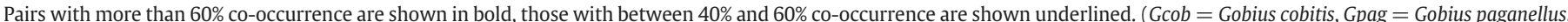

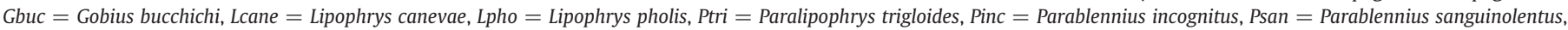

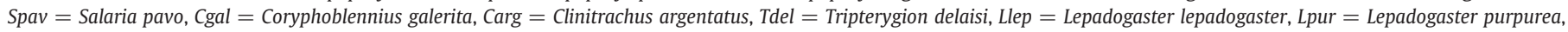
Lcand $=$ Lepadogaster candolii, Sroi = Symphodus roissali).

with the two species of blenniids, although the co-occurrence in both cases was less than $40 \%$. Dietary overlap was greater than $50 \%$ between $C$. galerita and $P$. incognitus, but the co-occurrence between species was low. The second group consists of G. cobitis, Salaria pavo and Paralipoprhys trigloides. The diet of S. pavo overlapped more than
$50 \%$ with that of G. paganellus, G. cobitis, G. bucchichi, C. galerita, P. incognitus and $P$. trigloides. However, the co-occurrence of $S$. pavo with these other species was low $(<40 \%$ in all the cases, except the case of G. paganellus). The species L. pholis and Parablennius sanguinolentus each form a group of one.

Table 3

Percentage occurrence of various categories of food in the guts of the different fish species.

\begin{tabular}{|c|c|c|c|c|c|c|c|c|c|c|c|c|c|c|c|c|}
\hline$\% \mathrm{~F}$ & Gpag & Gcob & Gbuc & Lpho & Lcane & Ptri & Pinc & Psan & Spav & Cgal & Carg & Tdel & Lpur & Llep & Lcan & Sroi \\
\hline CL. OSTRACODA & 19.9 & 8.5 & 19.3 & 1.3 & & 1 & 10.2 & & 13.4 & 15.3 & 5.3 & 18.9 & & 20 & & 39.5 \\
\hline CL. COPEPODA & 48.1 & 8.5 & 48.2 & 6.6 & 24 & 5.9 & 43 & & 24.4 & 35.6 & 2.6 & 54.1 & 7.4 & 20 & 40 & 57.9 \\
\hline O. CUMACEA & 9.1 & 8.5 & 16.9 & 4 & & 2.9 & 4.8 & & 6.1 & & 7.9 & 16.2 & & & & 15.8 \\
\hline SUbO. GAMMARIDEA & 29.1 & 5.1 & 25.3 & 8.6 & 10 & 17.7 & 35.5 & & 8.5 & 15.3 & 2.7 & & 3.7 & & & \\
\hline SUbO. CAPRELLIDA & 6.9 & 1.7 & 15.7 & 0.7 & & 8.8 & 18.8 & & 8.5 & 17 & 7.9 & 13.5 & & & & 5.3 \\
\hline O. AMPHIPODA (others) & 59.7 & 83.1 & 67.5 & 49.7 & 13 & 55.9 & 41.4 & & 58.5 & 28.8 & 81.6 & 89.2 & 40.7 & 60 & 80 & 76.3 \\
\hline F. SPHAEROMATIDAE & 13.5 & 6.8 & 1.2 & 4.6 & & 63.7 & 7.5 & & 2.4 & 3.4 & & & 7.4 & & & \\
\hline O. ISOPODA (others) & 13.5 & 11.9 & 12.1 & 25.2 & & 3.9 & 17.2 & & 17.1 & 5.1 & 13.2 & 27 & 18.5 & 20 & & 7.9 \\
\hline O. TANAIDACEA & 11.2 & 15.3 & 33.7 & 21.2 & & 56.9 & 15.6 & & 43.9 & 32.2 & & 13.5 & & & & 5.3 \\
\hline PH. CRUSTACEA NO DECAPODA (others) & 1 & 5.1 & 9.6 & 5.3 & & 2 & 2.7 & & 6.1 & 15.3 & & & & & & \\
\hline Brachynotus sexdentatus & 4.7 & 1.7 & & 2 & & 1 & 0.5 & & & & & & & & & \\
\hline F. PORCELLANIDAE & 1.8 & & & & & & & & & & & & & & 20 & \\
\hline F. PORTUNIDAE & 3.3 & & & 0.7 & & 3.9 & 0.5 & & & & & & & & & \\
\hline IO. BRACHYURA & 1.9 & & & 1.3 & & & & & & & & & & & & \\
\hline IO. CARIDEA & 4.6 & 5.1 & & & & 1 & & & & & & & & & & \\
\hline O. DECAPODA (others) & 3.1 & 10.2 & & 1.3 & & & 0.5 & & & & & 2.7 & & & & 2.6 \\
\hline Parvicardium mínimum & 5.7 & 1.7 & 14.5 & 1.3 & & 2.9 & 8.1 & & 1.2 & & & 16.2 & & & & 21.1 \\
\hline Lutraria sp. & 2.9 & & 7.2 & 2 & & 1 & 3.8 & & & & & & & & & \\
\hline CL. BIVALVIA (others) & 3.8 & 1.7 & 3.6 & 2.7 & & & 1.6 & & & & & 2.7 & 3.7 & & & 26.3 \\
\hline Acanthochitona fascicularis & 6.2 & 17 & 4.8 & 14.8 & & 46.1 & 1.6 & & 9.8 & & & & & & & 7.9 \\
\hline CL. POLYPLACOPHORA (others) & 0.8 & & & & & & & & & 1.7 & & & & 20 & 20 & \\
\hline Gibbula sp. & 2.2 & & 7.2 & 23.2 & & 7.8 & 2.7 & & 4.9 & & 2.6 & 24.3 & 3.7 & & & 55.3 \\
\hline Skeneopsis planorbis & 2.5 & 1.7 & 7.2 & 21.9 & & 29.4 & 4.3 & & 3.7 & 1.7 & & 2.7 & & & & 5.3 \\
\hline Omalogyra atomus & 1.5 & 1.7 & & 25.2 & 13 & 2 & & & 6.1 & 5.1 & & 13.5 & & & & 15.8 \\
\hline Barleeia rubra & 1.5 & 5.1 & 2.4 & 27.2 & & 12.8 & 2.2 & & 2.4 & & & 10.8 & 14.8 & & & 23.7 \\
\hline F. RISSOIDAE & 2.7 & & 12.1 & 14.6 & & 2.9 & 2.7 & & 6.1 & & 2.6 & 2.7 & 37 & & & 47.4 \\
\hline Patella Vulgata & 1.1 & 8.5 & & 16.6 & & 12.8 & & & 7.3 & 3.4 & & & & & & 2.6 \\
\hline CL. GASTROPODA (others) & 5.6 & & 9.6 & 37.8 & & 9.8 & 7 & & 6.1 & 3.4 & 5.3 & 2.7 & 11.1 & & & 18.4 \\
\hline PH. MOLLUSCA (others) & 2.9 & & 16.9 & 0.7 & & & & & & & & & & & & \\
\hline F. NEREIDAE & 16.2 & 22 & 21.7 & 14.6 & & 35.3 & 4.8 & & 17.1 & 8.5 & 5.3 & 18.9 & 7.4 & & & 10.5 \\
\hline F. EUNICIDAE & 1.8 & 5.1 & 4.8 & & & 3.9 & 0.5 & & 6.1 & 1.7 & & & & & & \\
\hline CL. POLICHAETA (others) & 7.7 & 20.3 & 14.5 & 4 & 15 & 6.9 & 10.8 & & 14.6 & 20.3 & & 10.8 & & & & \\
\hline F. CHIRONOMIDAE & 14.2 & 10.2 & 8.4 & 12.6 & & 26.5 & 12.9 & & 19.5 & 15.3 & & 37.8 & & & 20 & 10.5 \\
\hline O. DIPTERA & 3.3 & 1.7 & 9.6 & 3.3 & & 6.9 & 9.1 & & & 1.7 & & & & & & \\
\hline O. ACARINA & 10.9 & & 16.9 & 0.7 & & 11.8 & 7 & & 1.2 & 17 & & 5.4 & 3.7 & & & 7.9 \\
\hline O. ARANEAE & 2 & & 2.4 & & & & 5.4 & & & 1.7 & & & & & & \\
\hline Ph. PYCNOGONIDA & 11.8 & 1.7 & 10.8 & & & 12.8 & 6.5 & & 8.5 & & & 27 & & & & 5.3 \\
\hline OTHERS & 10.7 & 17 & 6 & & & 3.9 & 32.9 & & 1.2 & 8.5 & & & & & & \\
\hline Filamentous green ALGAE & 3.7 & 8.5 & 9.6 & 6.6 & 100 & 4.9 & 31.7 & 100 & 28 & 33.9 & & & 3.7 & & & 18.4 \\
\hline
\end{tabular}

Abbreviations of the fish species as in Table 2. 
Table 4

Composition of the diet of the different fish species based in the relative abundance (\%N).

\begin{tabular}{|c|c|c|c|c|c|c|c|c|c|c|c|c|c|c|c|c|}
\hline$\% \mathrm{~N}$ & Gpag & Gcob & Gbuc & Lpho & Lcane & Ptri & Pinc & Psan & Spav & Cgal & Carg & Tdel & Lpur & Llep & Lcand & Sroi \\
\hline CL. OSTRACODA & 3.26 & 2.01 & 2.89 & 0.11 & & 0.08 & 2.33 & & 3.77 & 1.91 & 2.06 & 1.80 & & 12.50 & & 3.69 \\
\hline CL. COPEPODA & 42.84 & 3.69 & 38.99 & 2.08 & 54.55 & 0.49 & 26.81 & & 13.40 & 42.61 & 4.12 & 23.15 & 4.92 & 12.50 & 26.67 & 29.49 \\
\hline O. CUMACEA & 2.84 & 1.68 & 3.27 & 0.32 & & 0.33 & 0.75 & & 0.94 & & 3.09 & 1.80 & & & & 2.64 \\
\hline SUbO. GAMMARIDEA & 7.29 & 1.68 & 3.90 & 1.12 & 4.55 & 3.18 & 12.91 & & 2.26 & 2.96 & 2.06 & & 1.64 & & & \\
\hline SUbO. CAPRELLIDA & 1.10 & 0.34 & 2.77 & 0.05 & & 3.18 & 5.33 & 9.09 & 2.83 & 3.48 & 3.09 & 1.40 & & & & 0.13 \\
\hline O. AMPHIPODA (others) & 14.05 & 35.57 & 13.58 & 12.61 & 22.73 & 12.41 & 12.57 & & 21.13 & 4.52 & 68.04 & 18.96 & 26.23 & 37.50 & 53.33 & 23.61 \\
\hline F. SPHAEROMATIDAE & 2.94 & 1.34 & 0.13 & 0.53 & & 18.29 & 1.42 & & 0.38 & 0.35 & & & 4.92 & & & \\
\hline O. ISOPODA (others) & 1.92 & 4.36 & 1.51 & 3.31 & & 0.33 & 3.33 & & 4.53 & 0.52 & 7.22 & 2.20 & 8.20 & 12.50 & & 0.99 \\
\hline O. TANAIDACEA & 1.97 & 6.71 & 5.41 & 7.00 & & 16.41 & 3.08 & & 21.32 & 25.04 & & 1.00 & & & & 0.13 \\
\hline PH. CRUSTACEA NO DECAPODA (others) & 0.18 & 1.34 & 1.51 & 2.14 & & 0.16 & 0.58 & & & 1.57 & & & & & & \\
\hline Brachynotus sexdentatus & 0.79 & 0.67 & & 0.16 & & 0.08 & 0.08 & & & & & & & & & \\
\hline F. PORCELLANIDAE & 0.23 & & & & & & & & & & & & & & 6.67 & \\
\hline F. PORTUNIDAE & 0.41 & & & 0.05 & & 0.41 & 0.08 & & & & & & & & & \\
\hline IO. BRACHYURA & 0.29 & & & 0.11 & & & & & & & & & & & & \\
\hline IO. CARIDEA & 0.73 & 1.01 & & & & 0.08 & & & & & & & & & & \\
\hline O. DECAPODA (others) & 0.38 & 2.01 & & 0.11 & & & 0.08 & & 0.94 & & & 0.20 & & & & 0.07 \\
\hline Parvicardium mínimum & 0.88 & 0.34 & 1.51 & 0.16 & & 0.24 & 1.42 & & 0.19 & & & 2.00 & & & & 0.99 \\
\hline Lutraria sp. & 0.38 & & 0.75 & 0.16 & & 0.08 & 0.83 & & & & & & & & & \\
\hline CL. BIVALVIA (others) & 0.47 & 0.34 & 0.38 & 0.21 & & & 0.25 & 9.09 & & & & 0.20 & 1.64 & & & 1.52 \\
\hline Acanthochitona fascicularis & 0.96 & 5.03 & 0.50 & 2.30 & & 14.69 & 0.25 & & 2.45 & & & & & & & 0.33 \\
\hline CL. POLYPLACOPHORA (others) & 0.09 & & & & & & & & & 0.17 & & & & 25.00 & & \\
\hline Gibbula sp. & 0.27 & & 1.13 & 4.97 & & 1.06 & 0.75 & & 1.51 & & 1.03 & 7.98 & 1.64 & & & 14.71 \\
\hline Skeneopsis planorbis & 0.41 & 1.01 & 0.88 & 10.74 & & 6.94 & 1.08 & & 0.57 & 0.52 & & 0.20 & & & & 0.20 \\
\hline Omalogyra atomus & 0.23 & 1.34 & & 8.93 & 9.09 & 0.33 & & 27.27 & 0.94 & 0.52 & & 1.80 & & & & 0.86 \\
\hline Barleeia rubra & 0.23 & 1.34 & 0.25 & 9.46 & & 1.63 & 0.33 & 9.09 & 0.38 & & & 12.77 & 6.56 & & & 6.93 \\
\hline F. RISSOIDAE & 0.34 & & 2.01 & 6.04 & & 0.24 & 0.50 & 9.09 & 0.94 & & 1.03 & 0.20 & 31.15 & & & 11.15 \\
\hline Patella vulgata & 0.14 & 7.38 & & 1.87 & & 1.47 & & & 2.26 & 0.70 & & & & & & 0.07 \\
\hline CL. GASTROPODA (others) & 0.82 & & 1.26 & 21.43 & & 0.98 & 4.16 & & 2.08 & 0.35 & 2.06 & 9.78 & 4.92 & & & 1.39 \\
\hline PH. MOLLUSCA (others) & 0.50 & & 3.27 & 0.05 & & & & & & & & & & & & \\
\hline F. NEREIDAE & 2.59 & 4.70 & 3.27 & 1.87 & & 4.57 & 0.75 & 9.09 & 4.15 & 0.87 & 2.06 & 1.60 & 3.28 & & & 0.53 \\
\hline F. EUNICIDAE & 0.23 & 1.34 & 0.50 & & & 0.49 & 0.08 & & 1.51 & 0.17 & & & & & & \\
\hline CL. POLICHAETA (others) & 1.11 & 5.70 & 1.64 & 0.37 & 9.09 & 0.57 & 2.08 & 9.09 & 2.26 & 6.61 & & 0.80 & & & 6.67 & \\
\hline F. CHIRONOMIDAE & 2.99 & 2.01 & 1.01 & 1.39 & & 6.78 & 2.58 & 9.09 & 7.36 & 1.91 & & 7.98 & & & 6.67 & 0.26 \\
\hline O. DIPTERA & 0.55 & 0.34 & 1.64 & 0.27 & & 0.73 & 2.08 & & & 0.17 & & & & & & \\
\hline O. ACARINA & 2.03 & & 3.65 & 0.05 & & 1.55 & 1.25 & & 0.19 & 3.65 & & 0.80 & 1.64 & & & 0.20 \\
\hline O. ARANEAE & 0.26 & & 0.25 & & & & 0.92 & & & 0.17 & & & & & & \\
\hline Ph. PYCNOGONIDA & 1.74 & 0.34 & 1.38 & & & 1.88 & 1.17 & & 1.51 & & & 2.79 & & & & 0.13 \\
\hline OTHERS & 1.55 & 6.38 & 0.75 & & & 0.33 & 10.16 & 9.09 & 0.19 & 1.22 & 4.12 & 0.60 & 1.64 & & & \\
\hline Filamentous green ALGAE & + & + & + & + & +++ & + & ++ & +++ & ++ & ++ & & & + & & & ++ \\
\hline
\end{tabular}

Algae present + , frequent ++ , abundant +++ . Abbreviations of fish species as in Table 2 .

\section{Discussion}

In this study we have investigated the dietary overlap of several cooccurring species of intertidal fishes. Our results indicate that dietary

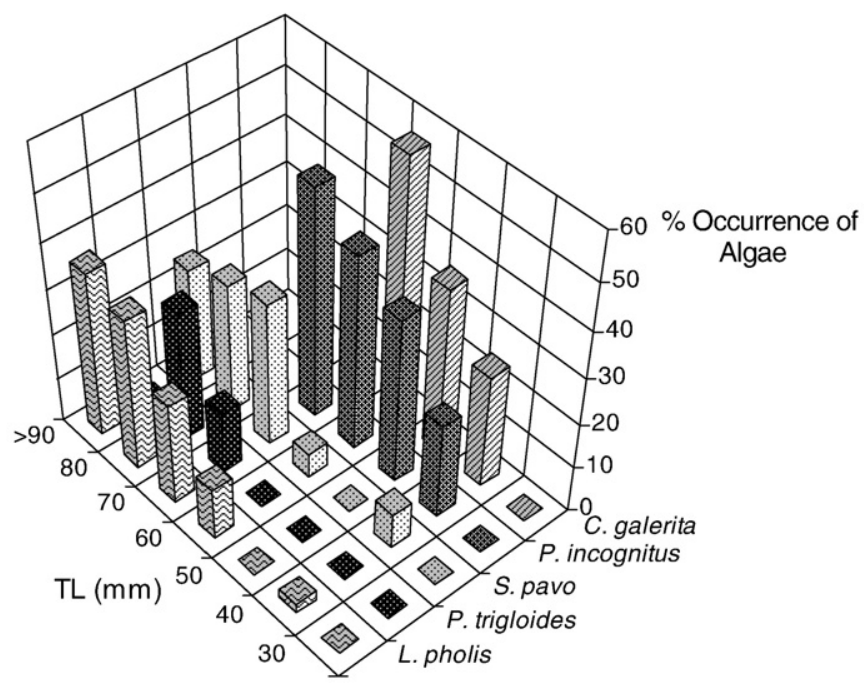

Fig. 1. Consumption of algae by the different blenniids according to their size ( $\mathrm{TL}=$ total length). overlap of intertidal fish species may be of minor importance because of relatively high density of prey in the rocky intertidal habitats. Even when not directly consumed by fish, sessile invertebrates, algae, and plants provide habitat and food for a wide variety of mobile invertebrates, including gammarid and caprellid amphipods, isopods, crabs, shrimp, errant polychates, gastropods, and chitons, that are major components of the diets of rocky intertidal fishes (Norton and Cook, 1999). We found 8 carnivorous species (Gobius paganellus, G. cobitis, G. bucchichi, Clinitrachus argentatus, Tripterygion delaisi, Lepadogaster

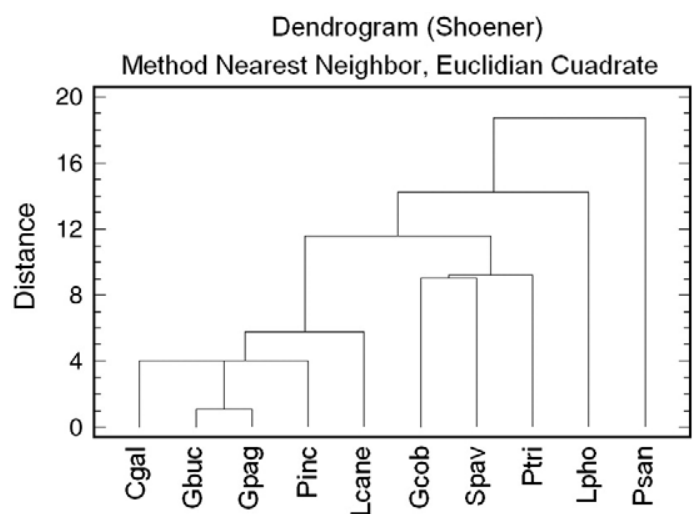

Fig. 2. Dendrogram based on the coefficient of Shoener's index of dietary overlap in the different species. Abbreviations of the different fish species as in Table 2. 
lepadogaster, L. purpurea and L. candolii), each with a percentage of occurrence of algae in the diet below $10 \%, 6$ omnivorous species that are carnivorous earlier in their lives and gradually increase the proportion of algae in their diet (Lipophrys pholis, Paralipophrys trigloides, Parablennius incognitus, Salaria pavo, Coryphoblennius galerita and Symphodus roissali) and 2 herbivorous species (Lipophrys canevae and Parablennius sanguinolentus). Interspecific and intraspecific competition in the studied assemblage has not been usually observed as other authors have pointed out (Carvalho, 1982; Milton, 1983), but in the case where competition does exist, it is based on the kind and the size of prey, as observed by Zander and Berg (1984).

Concentration on relatively few prey groups means that dietary overlap can sometimes be high but differences in the relative proportions of the main prey types are usually recognizable, suggesting that available prey resources are being partitioned. Gobius bucchichi and G. paganellus, which have a significant dietary overlap and a high species co-occurrence, ingested energy by feeding on larger organisms, such as crabs (which have a high energetic value). Lipophrys pholis eats mainly gastropods and increases its algal consumption with increased size, as do other blenniids (Paralipophrys trigloides, Salarias pavo, Parablennius incognitus and Coryphoblennius galerita). Parablennius sanguinolentus and Lipophrys canevae, being two of the few herbivores in the temperate intertidal (Gibson and Yoshiyama, 1999), feed mainly on the algae that grow on the walls and boulders of the pools where they live.

Additionally, differences in the size of fishes have been observed. Adult gobiids Gobius cobitis and G. paganellus, as well as adult Coryphoblennius galerita and Lipophrys pholis, present significant difference in size, with the largest species being two or three times longer than the smallest one (see Table 3). Faria and Almada (2001a, 2001b) hypothesized that these differences could have evolved through past interspecific competition (slight differences in anatomy and behaviour of the ancestors of the larger species could have allowed more efficient acquisition of larger prey, faster growth and expansion into niches not usable by the smaller member of a co-occurring pair, even without competition) or by other mechanisms. Often, in spite of a high observed dietary overlap, spatial segregation results in a low cooccurrence of species. This is for example the case of $C$. galerita and Parablennius incognitus, which have similar diets but live in different kinds of pools.

In this study, we have shown how following different specialization strategies (the common use of abundant resources and the specific use of certain types of resources) allow different species to minimise the effects of possible trophic competition among them.

\section{Acknowledgments}

This study has been undertaken within the project 'Environmental study of the Torregorda Testing Centre,' financed by the Ministry of Defence, and co-financed by the OPAM (Interreg IIIA Spain Morocco Project). The authors express their gratitude to all those who participated in the field samplings, without whom this study would not have been possible, and to all our friends who helped with reviews and English.

\section{References}

Almada, V.C., Carreiro, H., Faria, C., Gonçalves, E.J., 1996. The breeding season of Coryphoblennius galerita in Portuguese waters. J. Fish Biol. 48, 295-297.

Carvalho, F.P., 1982. Ethologie alimentaire de trois poissons blenniidae de la côte Portuguese. Boletim da Sociedade Portuguesa de Ciências Naturais 21, 31-43.
Colwell, R.K., Futuyma, D.J., 1971. On the measurement of niche breadth and overlap. Ecology 52, 567-576.

Davis, J.L.D., 2000. Spatial and seasonal patterns of habitat partitioning in a guild of southern California tidepool fishes. Mar. Ecol. Prog. Ser. 196, 253-268.

Faria, C., Almada, V., 2001a. Microhabitat segregation in three rocky intertidal fish species in Portugal: does it reflect interspecific competition? J. Fish Biol. 58, 145-159.

Faria, C., Almada, V., 2001b. Agonistic behaviour and control of access to hiding places in two intertidal blennies, Lipophrys pholis and Coryphoblennius galerita (Pisces: Blenniidae). Acta Ethologica 4, 51-58.

Faria, C., Almada, V.C., Gonçalves, E.J., 1996. Juvenile recruitment, growth and maturation of Lipophrys pholis (Pisces: Blenniidae), from the west coast of Portugal. J. Fish Biol. 49, 727-730.

Faria, C., Almada, V.C., Do Carmo Nunes, M., 1998. Patterns of agonistic behaviour shelter ocupation and habitat preferente in juvenile Lipophrys pholis, Coryphoblennius galerita and Gobius cobitis. J. Fish Biol. 53, 1263-1273.

Gibson, R.N., 1982. Recent studies on the biology of intertidal fishes. Oceanogr. Mar. Biol. Annu. Rev. 20, 363-414.

Gibson, R.N., Yoshiyama, R.M., 1999. Intertidal fish communities. In: Horn, M.H., Martin, K.L.M., Chotkowski, M.A. (Eds.), Intertidal fishes: life in two worlds. University of California Press, Berkeley, CA, pp. 264-296.

Griffiths, S.P., 2000. The use of clove oil as an anaesthetic and method for sampling intertidal rockpool fishes. J. Fish Biology 57, 1453-1464.

Illich, I.P., Kotrschal, K., 1990. Depth distribution and abundance of northern Adriatic littoral rocky reef blennioid fishes (Blenniidae \& Tripterygion). P. S. Z. N. I. Mar. Ecol 11, 277-289.

Krebs, C.J., 1989. Estimating community parameters. Ecological Methodology. HarperCollins, New York, pp. 291-408.

Macpherson, E., 1994. Substrate utilisation in a Mediterranean littoral fish community. Mar. Ecol. Prog. Ser. 114 (3), 211-218.

Mayr, M., Berger, A., 1992. Territoriality and microhabitat selection in two intertidal New Zealand fish. J. Fish Biol. 40, 243-256.

Mazé, R.A., 2004. Seasonal and ontogenetic diet shifts in an intertidal population of Gobius paganellus (Teleostei, Gobiidae) from the Cantabrian coast. Vie Milleu 54 (1), 1-6.

Milton, P., 1983. Biology of littoral blenniid fishes on the coast of south-west England. J. Mar Biol. Assoc. U.K. 63, 223-237.

Monteiro, N.M., Santos, A.M., Bacelo, J., 1998. Preliminary results on the diets of rocky intertidal fishes of the Northren Porguese Coast. Intl. Symp. Behav. Ecol. Littoral Fishes. Lisboa, Portugal.

Monteiro, N.M., Quinteiras, S.M., Silva, K., Vieira, M.N., Almada, V.C., 2005. Diet preference reflects the ontogenteic shift in microhabitat use in Lipophrys pholis. J. Fish Biol. 67, 102-113.

Moranta, J., Reviriego, B., Coll, J., 1997. Contribución al conocimiento de la estructura de la comunidad íctica asociada a los fondos rocoso litorales de las islas del Toro y d'Es Malgrat (suroeste de Mallorca, Islas Baleares). Publ. Espec. Inst. Esp. Oceanogr. 23, 143-152.

Morton, J.K., Platell, M.E., Gladstone, W., 2008. Differences in feeding ecology among three co-occurring species of wrasse (Teleostei: Labridae) on rocky reefs of temperate Australia. Mar. Biol. 154 (3), 577-592.

Nieder, J., 1993. Distribution of juvenile blennies (Coryphoblennius galerita and Lipophrys pholis, Pisces, Blenniidae) in small tide-pools on the Algarve coast of southern Portugal: result of low-tide lottery or strategic habitat selection? Bonner zoologische Beiträge 44, 133-140.

Nieder, J., 1997. Seasonal variation in feeding patterns and food niche overlap in the Mediterranean blennies Scartella cristata, Parablennius pilicornis and Lipophrys trigloides (Pisces: Blenniidae). P. S. Z. N. Mar. Ecol. 18 (3), 227-237.

Norton, S.F., Cook, A.E., 1999. Predation by fishes in the intertidal. In: Horn, M.H., Martin, K.L.M Chotkowski, M.A. (Eds.), Intertidal fishes: life in two worlds. University of California Press, Berkeley, CA, pp. 223-263.

Vicent, J.J., Aparici, V., 1997. Ecología trófica primaveral de Aidablennius sphynx (Valenciennes, 1836), Parablennius incognitus (Bath, 1968) y Lipophrys dalmatinus (Steindachner y Kolombatovic, 1883) (Pisces, Blenniidae) en las escolleras de las playas de Borrieana y Nules (golfo de Valencia, Mediterráneo occidental). Publ Espec. Inst. Esp. Oceanogr. 23, 161-170.

Zander, C.D., Berg, J., 1984. Feeding ecology of littoral Gobiid and Blennioid fishes of the Banyuls area (Mediterranean Sea).II. Prey selection and size preference. Vie Milieu $34(2 / 3), 149-157$.

Zaret, C.D., Rand, A.S., 1971. Competition in tropical stream fishes: support for the competitive exclusion principle. Ecology 52 (2), 336-342. 